\title{
PLAT wt Allele
}

National Cancer Institute

\section{Source}

National Cancer Institute. PLAT wt Allele. NCI Thesaurus. Code C49737.

Human PLAT wild-type allele is located within 8p12 and is approximately $32 \mathrm{~kb}$ in length.

This allele, which encodes tissue-type plasminogen activator protein, is involved in the regulation of plasmin-mediated proteolysis via the conversion of the proenzyme plasminogen to plasmin. 